\title{
EL LOGOS POÉTICO EN ANTONIO GAMONEDA
}

Ignacio VENTO VILLATE

Universidad Autónoma de Madrid

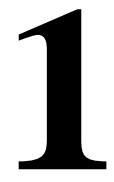

A menudo, trabajar sobre la obra de un creador supone tomarse una licencia que excede los propios méritos y violenta algunas de las ya escasas convicciones que, contra la infranqueable parquedad de la vida, nos vamos guardando. Mi más acendrada convicción puede enunciarse con sencillez: la recepción de una obra de arte se ha de corresponder con el estado estético que provoca y que habría de plasmarse en el surgimiento de otra nueva producción, pues la experiencia estética contagia y provoca un nuevo estado de conciencia, en diversos grados y modos.

Este artículo trata de la forma singular en la que hizo experiencia en mí la poética de Gamoneda, empero, para su justa evaluación, debo emplazar al lector a un diálogo con la experiencia propia que le cupiera descubrir. En cuanto a mi experiencia, se comprenderá que, dada mi formación, me vea en la necesidad de reseñar que en el presente ensayo surgirán algunas reflexiones filosóficas, aunque guardaré silencio sobre la influencia que sin duda tuvo en mi propia producción poética.

Debería comenzar por aquello que considero un error en el que suele incurrir el pensamiento teórico occidental y que justamente se inicia cuando se pretende que la experiencia que irrumpe en nosotros a través de la obra poética pueda ser considerada «reducible a los criterios de un discurso filosófico».

Dicho error parte de estudios que, como la poética aristotélica, se considera que lo esencial de lo poético puede expresarse mediante un proceso de apropiación teórica. La consecuencia es obvia ya que, de esta forma, se considera que el discurso filosófico delimita de forma privilegiada «lo que debe prevalecer» en la obra poética, adentrándose en la constitución en nuestra conciencia de una singular experiencia significativa de la realidad. Para mejor entenderlo, remito al lector a la propia poética de Aristóteles, a la trama de Las ranas de Aristófanes o a las diversas argumentaciones sobre la mímesis poética en La República libro X, de Platón. Muestras de la realidad de dicho conflicto, ya situándonos en un ámbito de reflexión más próximo, básteme con mencionar la obra de María Zambrano, Filosofía y poesía, para ubicar al lector en el interior del mismo.

Pues que el filósofo quiere lo uno porque lo quiere todo. Y el poeta no puede llegar a quererlo todo porque teme que en este «todo» no esté cada una de las cosas con sus variaciones, sus huellas y sus fantasmas. El poeta quiere cada una de las cosas sin restricción, sin abstracción, sin renuncia alguna (Zambrano, 1971, 126). 
Esta aparente competencia entre la poética y el pensamiento teórico -raíz del discurso filosófico-, compartido a lo largo de tantas edades, no es más que un rasgo de nuestra humana condición, es decir, de la «polaridad» que nos constituye en tanto amañadores de significados; pues ambos discursos buscan expresar el deseo de dar representación a la experiencia pura, a la conciencia de ese ingenuo ser-ahí-humano, con los instrumentos de una representación simbólica del quimérico «origen». Dicha búsqueda, singular y social, no deja de imbricarse entre las redes, tanto de nuestro imaginario, como de nuestra tradición conceptual.

¿Planteo, en consecuencia, el descrédito del pensamiento teórico o de la filosofía? No, pero, existiendo singularmente ambas, la cuestión estriba en la reivindicación de sendas singularidades y la comprensión de las razones de la anteriormente mencionada competencia. La filosofía y la poesía podrían haber ido de la mano, pero más de una vez han llegado, incluso, a ellas; siempre en demerito de la una y de la otra. Motivaciones que avalen tal competencia no han de faltar; bien porque la poesía había sido la memoria viva de la tradición cultural en las sociedades orales y, por lo mismo, ha ido condicionando la génesis del pensamiento occidental (Goody, J. 1977;1987; Havelock, E. A. 1962; 1982) bien porque esa singular forma de ejercer el pensar que denominamos filosofía, ha ascendido al poder social arrebatando al logos poético su posición en beneficio de ese otro logos, el teorético, conforme al cual toda experiencia puede e, incluso, debe ser expresada mediante una idea lógicamente acuñada en el ámbito del entendimiento puro.

Y si quisiéramos ofrecer un ejemplo de la obra en la que dicho conflicto concurre y, hasta donde sabemos, se inicia; es en la poesía de Parménides donde los caminos de ambos logoi son enfrentados ante la grave cuestión de que «lo dicho y pensado debe ser acerca de lo que hay... y y donde el pensador, a través de su propia poesía y bajo divino auspicio, proclama su esotérico criterio: «... ya que le cabe ser algo».

Como un argumento de la correlación entre el decir, el pensar y el ser de lo que debe prevalecer, el poema nos hace partícipe de su inconmensurable hallazgo: la intuición de la representación de lo real en el entendimiento humano: «Pues lo mismo hay para pensar y para ser. Mira pues lo que, aun ausente, está firmemente presente al entender» (Parménides DK 28 B 3; 4, 1).

A partir de dicho poema, se identifican tres modalidades de producir la representación -poiesisen el discurso o logos: el logos dialógico -siendo este con el que el propio Parménides juega y del que emergerá posteriormente un pensamiento dialéctico cuando Zenón y los sofistas se apropien de esta suerte de enfrentar los discursos porfiando en el interior de su forma argumental. El logos teórico, para el que únicamente cabe lo prevalente en el «entendimiento»-nous-como representación de la unidad, identidad, permanencia e inmutabilidad que han de caracterizar al Ser, es decir, «aquello que fundamente lo que hay» $\mathrm{y}$, finalmente, el logos poético.

Para propiciar el reconocimiento de esta diferenciación en los modos de discurrir o discursear, nada mejor que la inmersión en el poema de Parménides. Allí, la propia Aletheia, alegoría divina de la verdad permenídea, advierte al joven que, alejándose de los caminos seguidos por el común de los 
mortales, debe poner mientes en los siguientes argumentos: «Es necesario decir y pensar esto: que lo que es, es. Pues hay ser, Empero nada no la hay. Eso es lo que exhorto a meditar» (Parménides DK 28 B 6,$1 ; 8,1-52)$.

2. Veamos ahora, cómo caracterizaríamos, al logos poético sobre este mismo ámbito, del vincular el nombrar y el Ser -que es lo que, ampliamente, caracteriza al legein de los diversos discursos o Logoi. Partiendo del hecho de que todos pueden comprenderse como respuesta al más humano afán por representar lo que cabalmente es, en su aparecer.

Para comenzar, sería presuntuoso afirmar que lo histórico o lo biográfico pudiesen entrañar, en su acontecer, el barrunto de alguna forma de progresión cultural determinada por alguna forma de «necesidad» finalista. Así lo aprendí de otro maestro, H. Fränkel, cuando muestra en su asombroso libro Poesía y filosofía (1993) las difíciles relaciones habidas entre actividades humanas tan emparentadas como la poesía y la filosofía, sin embargo él también señala que ambos discursos se hayan vinculados a la necesidad de representarnos un mundo vivido con significado y sentido a partir de una experiencia que, en su extrañeza, no hace más que generar diversas tentativas por referir lo que hay.

Con estos precedentes y cautelas, adentrémonos en el discurrir poético de Antonio Gamoneda y tratemos de mostrar la presencia de estas modalidades del logos desplegándose en su confrontación. Así pues es momento de iniciarme señalando que Gamoneda pertenece a una poética que no hace alarde romántico ni filosófico en su discurrir poético por el camino inquisidor acerca de la humana condición -como Rainer María Rilke-, sino, con la mayor y mejor sobriedad castellana, deja llana constancia de ese mutuo reflejarse y referirse entre el pensamiento y la poesía.

Tomemos un ejemplo que se inicia al hilo de la revelación de un pueblo, levantado en medio de una tierra cuyo despoblamiento le invita a usar una descripción que, no por usual, deja de pertenecer al imaginario arcaico y que remite al Hades homérico: «deshabitada de pájaros» lo que nos evoca las condiciones de la desolación en los páramos castellanos:

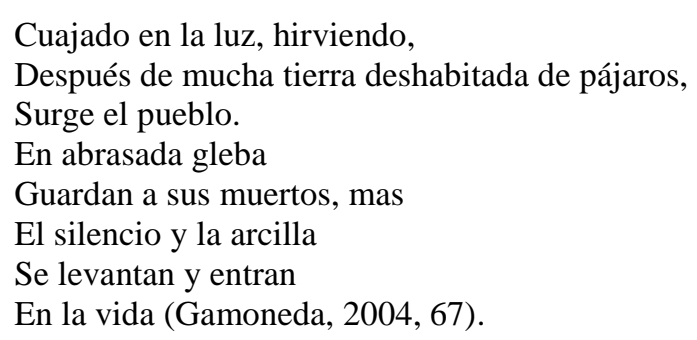

El hallazgo simbólico de la aproximación al pueblo, solidificado en el llano por la luz del resol, como cuajo que se espesase al hervir el calostro, es una clara experiencia poética. Esa apropiación de una singularidad que reseñara María Zambrano, se eleva a una experiencia total en su arquetípica y cabal verdad. Pero el poema avanza, va un poco más allá y comienza a establecer una dialéctica con el sentido de la relación entre la edificación y el modo en el que es habitado por sus moradores. Pues, para Gamoneda, en ese habitar, los muertos entran en la vida, lo que le abre una analogía con el 
pensamiento de Heráclito sobre el modo de habitarnos en la morada de nuestro propio cuerpo viviente: «Como una misma cosa está en nosotros lo viviente y lo muerto, así como lo despierto y lo dormido, lo joven y lo viejo...» (Heráclito. DK. 22 B 88).

La analogía se halla en esa intuición: aquello que hace comunidad, es análogo a lo que le hace pensar en el «hecho» de la armonía que somos en tanto seres vivos, de forma que será la experiencia de ese silencio que guarda a los muertos la que, como la arcilla que se extrae de la gleba y que, elevándose de su condición, llegue a formar parte de nuestra realidad.

Tal intuición es de una importancia vital, ya que crea un nuevo estado de conciencia que nos ofrece un atisbo del valor singular de lo que, en esa experiencia, llega a ser significativo.

Tal experiencia hace que el poema señale realidades a las que le cabe ser, es decir, el poema deviene la ocasión en la que se considera esa experiencia y se la representa, como monumento de un sentido, sin fundamento para otro discurrir que no fuera sino el de la remembranza. Si el pensamiento poético es de la estirpe de Mnemosyne -la memoriosa- la evocación poética quiere expresar cómo la experiencia singular del mundo en ese instante (pueblo) es convocación a la experiencia de su unidad como totalidad (comunidad). Y, aun, nos regala algo más. Un valor: belleza, ya que, Gamoneda hace al amor signo de esa experiencia de totalidad que se expresa quedamente:

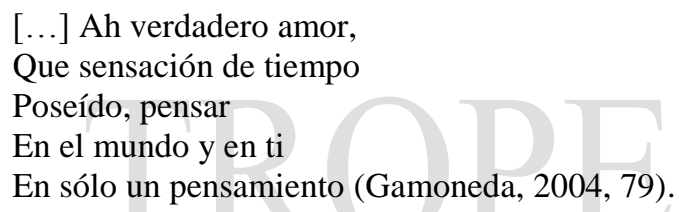

He de aplazar un tema como el de la belleza -hace falta ser valiente para enfrentarse a lo bello-, pero baste insistir en que el logos poético discurre a la par que el impacto estético, por lo que los rasgos de la realidad en su aparecer se hacen objeto de experiencia en la conciencia, como expresión de una totalidad. De esta forma, tanto lo singular como lo diverso, se transcienden a través un proceso de evaluación subjetiva puesta en acción desde y por dicha experiencia poética.

Así ha de reconocerse en el poema, ya que dicha intuición no va de la mano del pensamiento, sino de una correlación esencial: la edificación por y en el amor, junto a, la experiencia de la relación vida/muerte que se construye en el tiempo; siendo eso una experiencia de lo que en rigor es el fundamento de lo que hay; fundamento que llega al poeta mediante la observación que encadena intuiciones hechas experiencias significativas por su valor metafórico como imágenes que evocan y no por análisis de atributos inteligibles:

\author{
Pensaba la belleza. Veo ahora \\ Silencio edificado, corazones \\ Amontonados por el amor \\ Veo la vida en el centro de la luz; ya sé \\ Que la belleza no necesita ser pensada (Gamoneda, 2004, 67).
}


La belleza no necesita ser pensada. La experiencia poética se basta a sí misma. El discurrir del logos teórico del que nacerá el pensamiento filosófico, hace otra experiencia de un otro mundo que, solo puede ser inteligible, cuando es reducido a los esquemas y métodos del y para el entendimiento (nous). Dicho proceso exige un precio que se paga en favor de los arquetipos categoriales del ser esencial de lo que hay, para dejar de ser correlación entre sensibilidad, imagen y valor, tal y como vamos viendo que se da en el logos poético.

Podríamos referir varios intentos de vinculación del logos poético al teórico, como el del idealismo alemán de Schelling, pero nos daríamos cuenta, inmediatamente, que en su estética, el poema hace presente a la intuición las ideas sensibles precisas para llegar a una conmoción paradójica como paso imprescindible para el camino de la construcción de la conciencia. Por el contrario, el logos poético no se deja reasumir y superar en una idea sensible que devendrá «absoluta» en la intuición de la «idea» que la fundamenta; no puede abandonar esta mundanidad para introducirse en la esfera del «Espíritu» de la mano de la «Idea». Cada poema crea un mundo propio, que no es, ni siquiera, imagen fractal de una totalidad, sino un discurrir de la conciencia que ilumina y que, sin necesidad de llegar a ser el «fuego» platónico, no deja de «hacer visible» esa correlación esencial que nos vincula a la vida. Por lo tanto, el movimiento, a diferencia del idealista, no es exclusivamente ascendente, sino que se retroalimenta de continuo restableciendo el vínculo con su experiencia mundana.

Por ello, el logos poético es la fuente de los signos de lo que llega a ser y se siembra en nuestra cordialidad para hacer experiencia en nuestro corazón; esa vinculación mundana, afirmo, es unión entre la vida y el ser viviente y, por tanto, rebeldía del ser caído; del ángel que fuimos en la idealizada ingenuidad de nuestras primeras vivencias, pero, siempre, vestigios del Logos en el que nos constituimos, en tanto atributo moldeador de nuestra humanidad.

Cada poeta hace carne en este logos poético y lo encarna en su singularidad, cual modos de un espíritu modelado en el devenir de nuestra finitud, en el que se aúna la variabilidad infinita. Por ello, la poética de Gamoneda tiene sus propios trazos que nos ahondan en la pérdida de esa ingenuidad y del dolor que provoca; de las lecciones lentamente rumiadas que nos ofrecen el sufrimiento o la ventura; de la elevación de la materia cuando el sentimiento pone sobre ella la necesidad de una redención a través de la belleza.

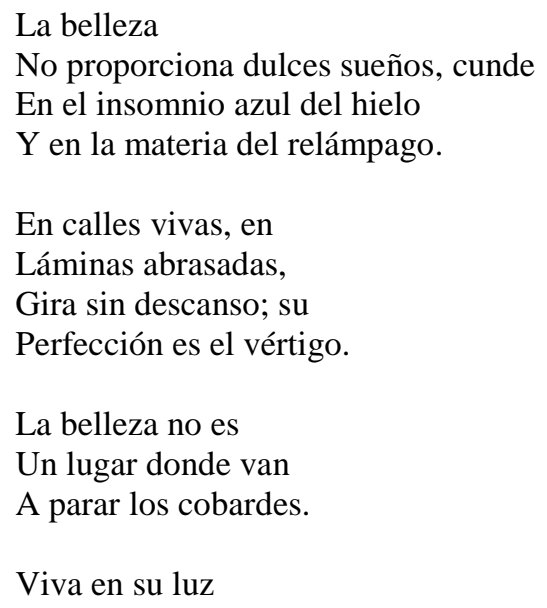


Mi pensamiento. Quiero

Morir en libertad (Gamoneda, 2004, 79).

Dicha experiencia poética construye una intuición única, una experiencia singular y oportuna -la oportunidad que hace de lo singular el trasunto de una totalidad-, Kairós que se construye desde ese Cronos que se inscribe en la temporalidad del sonido de la palabra justa y que, por ello, acoge la posibilidad de un transferirse a otros ámbitos de experiencia a través del imaginario que compartimos y que nos cimenta. Vivencia metafórica, si se precisa, cuyo sujeto demandado es el mismo y no el mismo -como lo son los objetos y las emociones-; para poder alcanzar, mediante el juego de los excedentes de significados que nos dona el empleo de la imaginación simbólica, el aión -la intemporalidad-que cantaran las musas de Hesíodo, esas que conocen de «lo que fue, es y será» como la esencia de toda verdad memorable $(2006,12)$.

3. Pero todo Logos, también el poético, está constituido por un utillaje, una tekné y una praxis que se hace tradición. Solo que nos hemos sentido más cómodos vinculándolo a la teoría del arte que a la artesanía. A pesar de que también en la artesanía se anticipa, se busca y se adquiere un modo de correspondencia entre la propia interioridad presente en la exterioridad; solo que, a menudo, hay una intencionalidad que se oculta a uno mismo y a los demás, de tal forma que la correspondencia precisa se establece en el poema como una silenciosa y mutua correlación, un fogonazo de sentido, una relámpago que ilumina una conciencia de mundo y otro modo de forjar la humanidad de lo humano.

Algo que no todos comparten; no Platón, desde luego, quien hará arteramente uso interesado de la artesanía para sostener la concepción del fundamento de todo lo que de inteligible hay en los entes, es decir, expresión de un arquetipo ideal. Pero como nos indican Adorno y Horkheimer:

\footnotetext{
El abismo que se abrió con tal separación lo ha percibido la filosofía en la relación entre intuición y concepto, y en vano ha intentado una y otra vez cerrarlo, ella es definida justamente por ese intento. Y casi siempre se ha puesto del lado del cual toma su nombre. Platón proscribió la poesía con el mismo gesto con que el positivismo proscribe la doctrina de las ideas (Horkheimer-Adorno, 2007, 33).
}

Decíamos, pues, que a la subjetividad y al mundo les es dado correlacionarse a través de la representación poética en cuyo espacio hace experiencia una singular conciencia. La forma del pensamiento que entonces desplegamos, no es sino la concurrencia que nos van constituyendo en y por el tipo de imaginario que vamos sabiendo que nos circunda «poéticamente». ¿Cómo lo encontramos expresado en Gamoneda?:

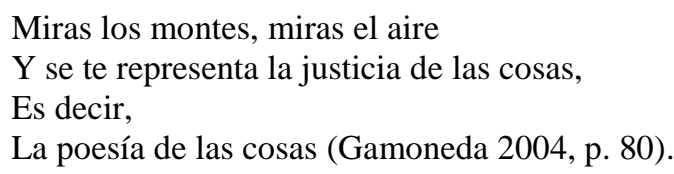

Aquí nos encontramos ante la intuición del mundo -que puede o no adquirirse con la mirada-; pero también ante el valor de la experiencia de ese mundo. A pesar de que partamos de la constatación de que en el mundo no hay valores, sino eventos y de que, considerado en su totalidad, el mundo es 
fruto de un ciego azar y no del ejercicio de una finalidad que se exprese en un orden, una justicia ni una bondad. Así, este mundo -como «este estado de cosas»-, no tendría ya remedio sin el concurso del discurrir poético; nada se enmendaría para volverse accesible, ni se elevaría desde la informe arcilla, como la vasija entre los hábiles dedos del tornero, pues que, a través de la mousiké, el logos poético crea la apreciación precisa, en la que al hacer concurrir aquello de lo que no podía tener intuición se hace emerger una experiencia original de cada objeto y sus relaciones.

Me doy cuenta que esto, dicho así, de una forma tan somera y concentrada, puede resultar extraño y ajeno a una interpretación tradicional, pero existe una interesante reflexión entorno a la hermenéutica de la experiencia simbólica que atañe a la raíz de la poética y que desearía que fuese asimilable bajo la comprensión de lo que estoy ensayando en este artículo (Sartre, 2005; Durand, 2007; Todorov, 2011; Eco, 1998; Sperber, 1988). Así que, como de lo que se trata es de, justamente, poner ante nuestra atención lo que lleva a cabo el Logos poético, espero que lleguemos a una cierta claridad o, al menos, a una penumbra con fulgores, como esas estancias atravesadas de polvorientos haces de luz. Con tal propósito, podemos comenzar por esa mousiké, para acercarnos, posteriormente a esas «emanaciones esenciales»: la conciencia y el mundo.

4. Así pues, hemos de tener presente, de nuevo, que la poesía se asienta sobre el ritmo y que, por tanto, la medida de la palabra significa el acomodo en una temporalidad propia que le confiera una estructura musical singular y caracterológica; apropiada a su tema y objeto; adecuada a nuestro placer sonoro y a nuestra capacidad de retención. Símbolo, pues, del enraizamiento de la disposición de los objetos en la sensibilidad del momento. Gamoneda no es ajeno a la conciencia de esta realidad que constituye el «basamento» de la poesía:

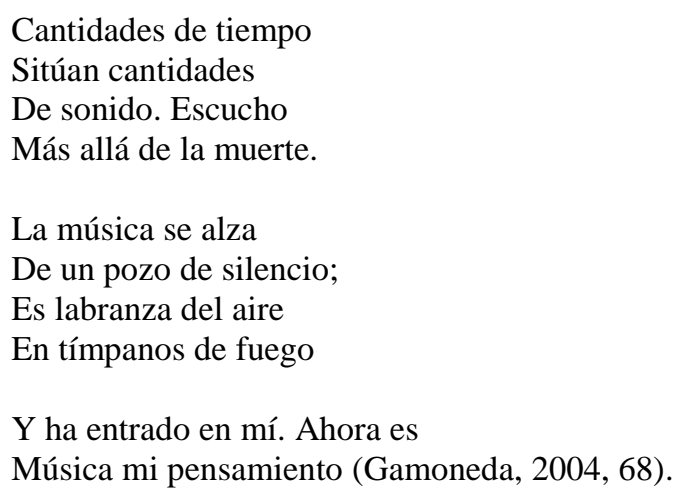

Lo aquí enfatizado, es todo lo contrario de lo que les caracteriza a los emprendedores del logos filosófico, pues, para ellos, una suerte de peligroso sortilegio hace que la representación de la experiencia discurra con facilidad y placer y sea introducida en la conciencia del ser humano a través del ritmado camino de la mousiké. Así, aunque Pitágoras y Platón asuman que la mousiké se abre paso hacia la conciencia, creen que hay que disponer de una senda de purificación para que la experiencia llegue a ser expresión de una verdad objetiva que se inscriba en el alma humana, en tanto que armonización con un fundamento trascendente. Por el contrario, el ritmo es para el logos poético el 
cauce y la expresión de la sensibilidad y las emociones humanas: expresión del pathos o capacidad de ser con-mocionado por la experiencia, de forma que este hace surgir la necesidad de construir el cauce rítmico que es, el mismo, su representación simbólica. Si tratásemos de aprehender tal fenómeno, comprobaríamos que, en tal acto, se produce la primera conjunción entre la experiencia de la materialidad sensible y la conmoción interior de los afectos; entre la impresión y la apreciación de un cambio de estado propio. Cuando la palabra dispone del vehículo del ritmo, tenemos a nuestro alcance la posibilidad de construir una experiencia vital inédita y, tal vez por ello, útil para expresar una impresión inmediata - como la mayoría de los valores o los sentimientos- contra la temible indeterminación de la existencia.

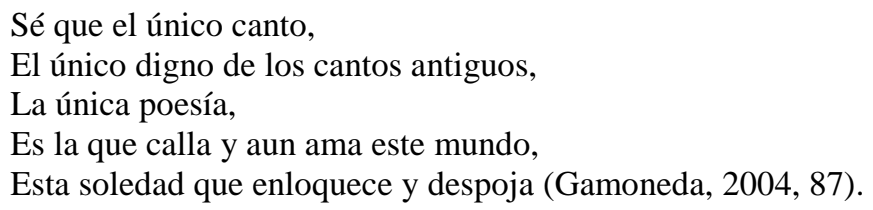

Nos encontramos aquí con un juego de correspondencias que son, por ello, un juego de medidas -pesos y cantidades- que se correlacionan. Pues el nombrar poético no es poca cosa cuando sopesa el mundo que crea, por el contrario, es una responsabilidad que se descubre y que demanda al propio creador. De ahí nace el valor: del atender a la justeza de las cosas, de apreciar su relación, evento, mundo y sujeto a un tiempo.

Pues este ritmo, no solo edifica el memento lenta y levemente, sino que demanda en el poeta una creciente experiencia de sí mismo; de la finitud, de la fragilidad, de la distancia que le separa de las otras personas o de los mundos que habita. Pues aquel que atiende, nombra y da a cada objeto el ser que le cabe, siente -al mismo tiempo- que otros muchos mundos quedaron en silencio y serán pasto del olvido. Pues, aquel que responde a la demanda de la creación, canta desde la muerte y el silencio, de forma que entre ellos y la carne se traza-metafóricamente hablando- un reguero de cenizas.

¿Cómo habrá de vivirse?, y lo que aun resulta una inquietud más dolorosa, ¿cómo será ese vivir para aquel que acoge el nombrar poético entre las demás formas del nombrar? ¿Cómo será para los demás seres, sobre todo, para los testigos más allegados? Tantea el poema de Gamoneda:

\footnotetext{
Si una rosa infinita me estallase en el pecho $\mathrm{Y}$, al llegar el crepúsculo, floreciera en mis labios, ¿Dejarías que fuese removiendo las sombras -porque vives en las sombras- con mis manos sedientas, Con caballos de insomnio galopando en mi frente, A ponerla despacio en tus hombros nocturnos?

Si una rama de fuego me brotase en la lengua, ¿Dejarías que fuese como un viento en la noche -Esa noche que tienes en tu voz y en tu casa-, A decirte en la espalda desnuda? (Gamoneda, 2004, 24).
}

Hoy nos asombra que exista el pinar y el ejido; que la caricia y el mordisco aniden en nuestros juegos desde siempre, pero, ¿qué anida en la experiencia vivida si no se nombra? Ese acto se vincula 
a un entramado de relatos mutuos con nuestro propio existir. Eso es lo que vamos aprendiendo de la vida: cómo hacer de la recolección molienda y de la harina pan que nos alimente para el camino. Por lo tanto, Adam fue un poeta, pues dio nombre a todas las cosas y tuvo por primera vez ante sí el riesgo de tal grandeza. El riesgo de endiosarse al decidir a qué habría de llamar a la existencia, a qué le cabía ser en la justeza de su arquetipo. ¿Cómo aventurarse a «dar el ser»? Se puede argüir desde el Logos teórico, que dar el nombre no es lo mismo que dar el ser. Pero, ¿que es algo sin nombre entre los seres del mundo? Menos que nada a la que nadie puede señalar ni convertir en sujeto y objeto de ninguna oración.

- $i \ll$ Nadie» me ataca! - grita Polifemo creyendo que, en su ceguera intelectual, era para todos evidente que estaba refiriéndose a alguien llamado «Nadie».

- ¡Pues si nadie te hace mal, deja de dar voces! -le responden los otros cíclopes para quienes, sin la presencia de la cosa, la ausencia de identificador les priva de cualquier experiencia de realidad (Homero, Odisea, IX, 400-411).

¿Cómo atender a tal riesgo? ¿Cómo asumir sin infatuación el don? Solo conozco, entre mis límites, dos caminos correctos a este respecto. El primero es el silencio, que implica, por supuesto, marginarse de la recreación del mundo y, por ello, no ser solidario con la inquietud humana que precisa responder ante su carencia de sentido. ¿Por qué yo? ¿Para qué afanarme durante noches de silenciosa atención que únicamente me hacen cómplice y víctima de este simulacro compartido? ¿Por qué concurrir con la palabra a esta babel de sin sentidos? ¿No perpetuaré, yo mismo, con mi pobre veleidad, este desatino? Así siente el poeta su vinculación con las terribles creencias que nos muestra una religión enraizada en la experiencia de la culpa y que se derrama en el poemario de Gamoneda como el corolario de una conciencia de sí que reclama la inocencia:

\author{
Madre quiero olvidar \\ Esta creencia sin descanso. Nadie \\ Ha visto un corazón habitado: \\ ¿Por qué este pensamiento irreparable, \\ Esta creencia sin descanso? \\ Estar desesperado, \\ Estar químicamente desesperado, \\ No es un destino ni una verdad. \\ Es horrible y sencillo \\ Y más que la muerte. Madre: \\ Dame tus manos, lava \\ Mi corazón, haz algo (Gamoneda, 2004, 88).
}

El otro, es el camino de la humilde servidumbre. No en vano el poeta del génesis -el yahwista-, que compuso oralmente el mito del paraíso, llamó a Adam «siervo» (Von Rad, 1988, 96). Como si expresara que el riesgo que entraña el don de nombrar al mundo que le cabe ser y que ha de habitar en toda conciencia desde ese instante, únicamente pudiera conjurarse considerándolo una labor entre las demás labores, es decir, como un servicio.

Este riesgo permanente se esconde en el acto mismo de nombrar y se alimenta en ese poderío, pudiendo arrastrar al poeta ensoberbecido al «Mal de Femio», que consiste en ser consciente de que 
se puede hacer de un cualquiera, a través del propio canto, un héroe y así convocarlo en la memoria de su pueblo a ser celebrado por las generaciones venideras en gestas jamás realizadas (Homero, Odisea, xxii, 330-380). Hay quien no se pliega a la voluntad omnímoda de la divinidad, como Casandra, que rechazando la total entrega al dios, alejó la posibilidad de servir a los familiares y allegados. La voluntad humana de decir la verdad prevalecería en ella, pero al no ser creída, al perder la confianza, sus vaticinios son como cáscara de arroz que se avienta y termina perdiéndose entre los espinos y rastrojos. Muy al contrario, el fiel servidor, Tiresias, conservó su mente intacta una vez muerto aunque reseca y, por tanto, necesitada de la sangre del negro lechal. Por ello le fue posible transmitir a Odiseo el requerido rumbo entre ese otro mar carente de rutas que es el futuro.

El riesgo de soberbia o hybris puede conjurarse, simbólicamente, con una pérdida física, pero también con la propia marginación o la propia entrega al sentido de lo oculto, ese ámbito silenciado de lo excluido y lo doliente; a ello se entrega Gamoneda:

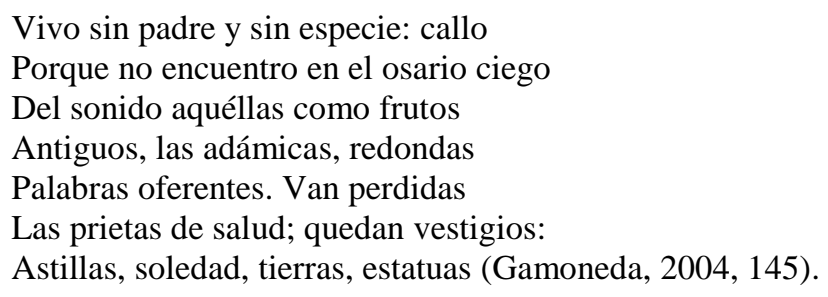

En la conciencia del mundo de aquel que discurre por el curso poético, ya nada volverá a ser lo mismo. Ni los árboles, ni los cauces, ni la llanura. Todo será ya, por siempre, trasunto de otra cosa; evidente o invisible, alegre o terrible, ¿quién lo sabe? Ya nada volverá a ser lo mismo. Y esa labor aparta. Antepone una hendidura, apenas apreciable, pero tangible en la visión de uno mismo y en la mirada de los otros. Un temor a lo extraño que te habita y te hace distante y distinto. Lamentaremos esa labor, pero irá con nosotros allá donde habitemos e impregnará aquello que hagamos, sin remedio. Pues el mundo llega con su parto, su luz y su sombra. Pues toda vida que mira más allá de sí mismo, es portadora de sus cenizas. Veamos su reflejo en el siguiente poema:

[...] Al hombre cuyo oficio y vigilancia

Es la vida, feroz como el mercurio Una bolsa de pena lo acompaña.

Está cansado sobre el propio rastro

Como un ave de plomo. Dormiría

Sobre todas las cosas: las miserias

Y las humillaciones y el olvido.

Pero si cierra el vigilante, cierra

La dentadura sobre la conciencia

Y no ve el rostro nunca y el espanto

Oprímele los ojos y se oculta

Entre los paños de la soledad,

Entonces, nada más, se ensucia, llora

Y no sale de su caja amarilla.

El hombre cuyo oficio y vigilancia

Es la vida ¿qué hará, cómo podría

Subirse encima de la enfermedad, 
Comprender y luchar? Bajé los ojos

Ante el mundo. Cubrí con una sombra Mi vergüenza y mi pena. Me dispuse

A una fraternidad sin esperanza (Gamoneda, 2004, 108-109).

He aquí el don, que se hace oficio con la música y que entraña orgullo y riesgo. Pero, ante ese momento de apariencia primordial, le atañe al poeta responder a las demandas de su don, a la habilidad de su oficio y a los riesgos de su poder.

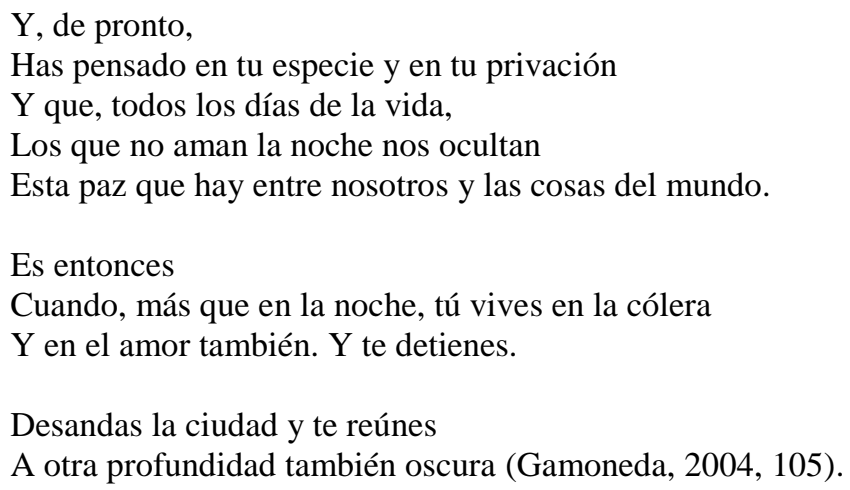

Desde los inicios de las culturas tribales, las gestas del grupo debían ser buscadas en el poeta cantor. En las sagas de los héroes locales y en los mitos, o en la obra del dramaturgo. En ello, siempre es reconocible que los personajes, los objetos y las acciones sean trasunto de un estado singular, de un valor compartido o de un juego de signos y señales que alimenta la enciclopedia cultural de cada población (Havelock, 1963, 61 s.; Vernant, 1965, 334; Redfield, 1975, 73 s.) De esta forma era alimentado el horizonte de sus expectativas y poblado de pecios su memoria colectiva (Buxton, R., 2003).

5. Con una crítica al poder de la mímesis poética querría Platón -señor de todos los logos-impedir que el discurrir poético se realizase sin el debido control por parte del nuevo criterio rector: el pensamiento filosófico (Platón, 1971, 604 e-608 b). Para el pensamiento filosófico la representación del mundo tiene ya otros criterios: otros rithmós que no se mide por los pies del verso, sino con el número y la medida aplicados a sus estructuras formales y su proceder funcional. Tales logismoi le permitirían introducir una nueva instrumentalidad entre lo aparente que se divulga y lo oculto que se vuelve prevalente en todo lo que puede llegarse a investigar. Pues, esencialmente, más allá de los sentidos, la esencial y la verdad están ya expeditas únicamente gracias a tales instrumentos de aprendizaje o mathémata.

Pues contra esta ilusiones, ¿no se han revelado como los más amables auxiliares el medir, el contar y el pesar, para que no llegue a imponerse en nosotros la apariencia de más o menos grande, o peso, sino la regla del cálculo y del peso? - ¿Cómo no? -Y ésta es, a no dudarlo, la obra del elemento razonador que hay en nuestra alma (Platón, 1971, v. 602 d6-e). 
De esta forma, quisiera el pensamiento filosófico privar al logos poético de su poder, para hacerse con el control sobre el nacimiento de la conciencia y hacer de la razón instrumental el gobernalle sobre el que pilotar el rumbo humano. Pero para esa maniobra, Platón hubo de hacerse traición a sí mismo y mantener oculto, tras la apariencia de la alegoría, el tesoro que ansiaba. Mostró las contradicciones lógicas, la ambigüedad semántica, las aberraciones morales y hasta la rareza con la que está distribuida entre los seres humanos los dones de las musas, pero, ¡ay!, en cuanto se rascaba el pensamiento de la costra de los diálogos y se introducía sobre los misterios de la existencia; allí le venía a las mientes la metáfora, el símbolo y era poseído por la poética manía divina que se apoderaba de su ecuánime inteligencia para escribir sus más bellas páginas. Así era en los tiempos antiguos, así le replican los actuales:

\author{
Sostiene fuego. \\ Sostiene una sombra, un \\ Cabello preparado \\ Con metales intensos. \\ En la columna viva, \\ El fugitivo tiempo \\ Se detiene. Así hacen, \\ Altos en la luz, inmóviles, \\ Los mármoles antiguos.
}

\title{
Ah cuello intocable de \\ Una muchacha cuyo \\ Corazón cogería \\ Con las manos, pondría \\ Los labios en él, haría \\ Alimento y destino (Gamoneda, 2004, 58).
}

Porque en los tiempos modernos, el ser humano no es meramente alma, sino una conciencia que se va constituyendo, como una crisálida, a lo largo la rememoración de lo acontecido y en la narración de sí mismo. Entonces, por fin, se comprende por qué la poesía debe dejar de ser el rival del Logos filosófico.

Con anterioridad, cuando la conciencia debía acaudalar únicamente aquello a lo que le cabía prevalecer en su esencial inteligir, el pensamiento fílosófico no pudo dejar de adueñarse de la educación de las almas humanas, pues perseguía ser reformador de la moral y la política. Pero hoy en día, para el pensamiento filosófico, la poética es aquella forma que construye la representación del mundo para dotar al hombre del imprescindible fármaco del sentido de su vivencia. Y ese proceso que conduce a hacer emerger el mundo, la conciencia y el valor, es una pócima que cura o envenena, conforme a la medida de su ingesta.

Sería oportuno que hiciera explícito cuál es la noción de conciencia que a la que aquí me voy refiriendo, ya que pueden confundirse con otros significados que parten de diversos estudios, desde la neurociencia a la filosofía de la mente. Y esta noción debe ser escueta y básica, ya que la concreción de la conciencia es una de los logros de la evolución más complejos que hay y que todavía no hemos logrado desentrañar ni comprender totalmente. Por ejemplo, es evidente que lo que afirmo sobre ella, 
podría atribuirse a otros seres con los que estamos emparentados filogenéticamente, pero que en el caso del ser humano viene a hacerse exponencialmente más complejo por la mediación nuestra ingente capacidad de representación simbólica, de comunicación lingüística y de creación de una cultura material.

Así pues, entiendo por conciencia el flujo en la memoria de los esquemas que la imaginación construye a partir de nuestra propia experiencia en correlación con los procesos vitales de nuestro cuerpo y las experiencias que este tiene del entorno. Pero, más allá de la definición, sigue esperándonos el sugerente índice del poema.

¿Y esto es la vida? No lo sé. Sé que se extingue como los círculos

Del agua. ¿Qué hacer entonces, indecisos entre la agonía y la serenidad?

No sé. Descanso.

En la ignorancia fría.

Hay una música en mí, esto es cierto, y todavía me pregunto qué significa este placer sin esperanza. Hay música ante el abismo, sí, y, más lejos, otra ve la campana de la nieve y, aun, mi oído ávido sobre el caldero de la penas, pero

¿Qué significa finalmente

Este placer sin esperanza?

Ya he hablado del que vigila en mí cuando yo duermo, del desconocido oculto en la memoria. ¿También él va a morir?

No sé. Carece

Desesperadamente de importancia (Gamoneda, 2004, 466).

Pero buscando mayor concreción, podría restringir la conciencia a la representación que portamos de nosotros mismos -ideas, creencias, imágenes, sentimientos, etc.- en correlación con nuestra capacidad para ser afectados en la experiencia, de tal forma que conformemos una imbricación personal en un «mundo» que es «nuestro mundo». No exclusivo ni discriminante, puesto que está forjado por múltiples elementos compartidos; desde los propios de nuestra co-pertenencia como humanos hasta los instrumentos culturales que nos permiten relacionarnos con el modo en que nos vemos afectados y la expresión que adquiere en nosotros.

En este último sentido, quizá sea más comprensible la concepción del Logos poético que aquí estamos mostrando gracias a la poesía de Antonio Gamoneda, así como la acción de su arte sobre el receptor de su poética. Porque la primera persona que experimenta dicha acción, es el mismo poeta, el propio Gamoneda en este soneto.

\footnotetext{
Suena mi oscura juventud suena Mi corazón extrañamente grave. Es silencioso Dios. Yo no. Quien sabe Por qué esta y tanta cantidad de pena.

Parece que es dolor lo que me llena Hasta la altura de los ojos. Cabe Vida y muerte en mi voz, pero no hay llave Para abrir el amor; sólo hay cadena.
} 
Lumbre lejana que me estás quemando

Y no me dejas verte y no me tocas:

Esto es un hombre, pero está llorando.

Sólo quiere vivir, pero en caliente.

Dime; ¿qué hago con las ganas locas

De ser agua en la sed, sed en la fuente? (Gamoneda, 2004, 35).

Yendo un paso más allá, añadiremos que lo propio de la poética es su índole simbólica, cuyo núcleo se constituye conformando el imaginario de su comunidad social y cultural -en la que venimos al significado-, a la privilegiada experiencia de uno mismo. Ahí anida la nueva conciencia del mundo propio.

Es él el alimento y el olvido;

Agua de juventud; se sobrepone

A toda división. Un dios antiguo

Abre sus venas en mi sangre y fluye

Hasta cansar mi corazón. El zumo

De la serenidad hierve en mi boca;

Cojo el secreto con la lengua, pero

Más me coge él a mí. Ramas tranquilas

Bajan el mosto hasta mis labios. Él

Roba la muerte de mis huesos. Habla

Como un mirlo esparcido y todo el bosque

Abre sus frutos y los manantiales

Manan lentos en mí. Pero llorando (Gamoneda, 2004, 148).

6. El pensamiento poético es la experiencia del modo en que se construye el co-res-spondeo, entre el mundo y la conciencia. No existen el Yo y las Circunstancias. No existe un entre el mundo y la conciencia. Existe la plena experiencia de que soy en la conciencia del mundo, el cual se hace significativo en el acto poético por el que se fragua y de cuya realidad emana un sentido tras otro, también de mí mismo. Con todo, este proceso es abierto a un excedente de sentido, porque se halla inmerso en una experiencia mediadora que, con cada lengua, a través del imaginario compartido, se enraíza en la tradición social y cultural de cada grupo.

La ciudad mira el sílice de las montañas como una gárgola inmóvil ante los círculos de la eternidad y se rodea de colinas cárdenas en las que el tomillo es abrasado por el invierno. Siento la espesura fluvial; que se manifiesta en sílabas lentísimas. Aún las palomas se pronuncian clamorosas y los ancianos descansan en la cercanía de las acacias coronadas de temblor. Hablan y acrecientan la serenidad de la tarde.

A veces, sonríen con un golpe de sol en el rostro y se encienden bajo los encanecidos cabellos. Sus ojos se entrecierran y apenas es visible un filamento de acero y lágrima. La vejez es blanca.

Un anciano viene abatido y dispar; el otro ofrece al sol unas manos grandes cuya piel transparenta largas venas. Hablan con la imprecisión temblorosa de quien es más débil que sus recuerdos; restablecen una paz y un espacio: las eras de la ciudad, los labradores de Renueva, el espesor de los curtidores, la sombra roja de las herrerías (Gamoneda, 2004, 51).

Surgen entonces la posibilidad de hacer mención de la comunidad temática, de la comunidad histórica de experiencias compartidas, en una o varias lenguas, de adentrarse en lo singular de cada pensamiento poético y ser remitidos a otros fenómenos tan ricos y apasionantes como a los que me he querido limitar en estos poemas. Así, en Gamoneda existe una constante en la construcción de su 
poética que, referida a su conciencia, le constituye singularmente como un hombre que va pefilando su dimensión humana y ética. Un descubrimiento que se reveló, incluso, tempranamente.

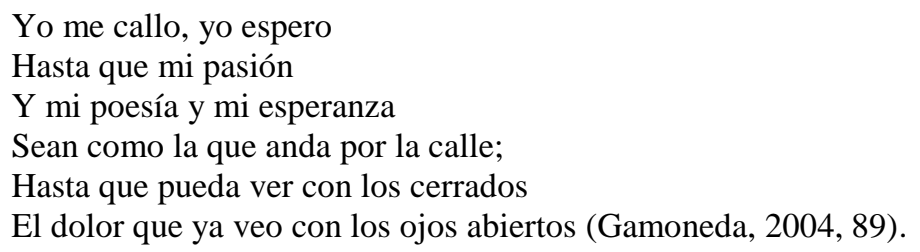

Esta singular conciencia ética, no es otra que la propia que se desprende del choque entre la belleza y contemplación de un mundo que se vuelve, a menudo, desolado. Un mundo que comienza con el descubrimiento del juego de la identidad y la alteridad en el eros.

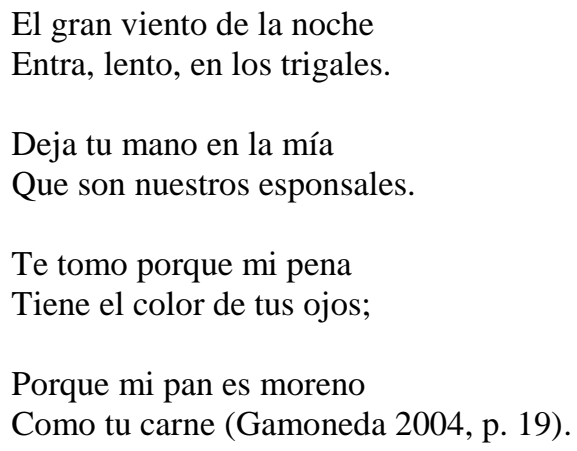

Allí donde uno descubre su mismo otro; allí donde se reconoce o cree reconocer en la radical holgura del género, algo de lo propio de sí, ruega acceder/como oferente: el brillo, el temor, la oscuridad y otros signos de un mundo hecho, hasta ahora, de resonancias internas, pide ser acogido y quedar a salvo, bajo el amparo sagrado del amor.

\footnotetext{
Reina de mi sangre, voluntad de amargura, Juventud derrotada por un reino de sombras, Te meces en mis brazos como un mar; incesante Como un mar me nombras.

En mí acaba tu cuerpo. Hay palabras oscuras Habitando tus ojos. Desnúdate en mis manos.

Viene la noche. Es

La hora de perderme en tu cabello y tu llanto (Gamoneda, 2004, 26).
}

Porque, aunque el Logos teórico esté enfrascado en la experiencia de semejantes manifestaciones que emergen en la imaginación, este busca el orden esquemático de carácter abstracto y puro, de forma que alcanza, a través de tal methesis, al arquetipo ideal con el que el pensamiento filosófico pretende planificar la reforma del hombre y de la sociedad. Por el contrario, es el Logos poético -la experiencia artística, si generalizamos- el que sabe trazar las mediaciones entre ese ser humano, inquieto y vulnerable, con un mundo aventurado. 
Despedir un sonido de alegría;

Quizá sueno a materia desollada.

Me justifico en el dolor. No hay nada;

Yo no encuentro en mis huesos cobardía.

En mi canto se invierte la agonía;

Es un caso de luz incorporada.

Propongo mi cabeza por si hubiera

Necesidad de soportar un rayo.

No hablo por mí solo. Digo, juro

Que la belleza es necesaria. Muera

Lo que deba morir; lo que callo.

No toques, Dios, mi corazón impuro (Gamoneda, 2004, 51).

7. Cuando el Logos poético comienza a emerger a la luz y hace de sí mismo objeto de su labor, descubre que se adentra en un horizonte sin lindes y brumoso, del que únicamente se columbran reflejos y sombras. Desde la fenomenología, la poesía ha sido considerada como un ámbito singular en el que la subjetividad parece emerger en relación con la forma con la que se apercibe uno a sí mismo en y por el aprecio del mundo. La fenomenología le otorgaría un rango ontológico al vincular los dos polos, el subjetivo y el objetivo, en el contexto de la correlación, el rango de un des-velamiento y, con ello, abriendo la experiencia a la posibilidad de un reconocimiento en la existencia (Heidegger, 1990).

Con todo, la gran diferencia entre el pensamiento filosófico y el poético es que, mientras este perpetúa su eficaz resonancia en la comprensión, aquel, por el contrario, permanece anclado en su concepción intelectual del conocimiento. Y no es lo mismo, comprenderse a uno mismo que conocerse (Blumenberg, 2002). Uno mismo es un mundo por descubrir, una terra ignota a la que las meras ideas no alcanzan, sino al que hay que aprender a desliar hebra con hebra, sabor con sabor, color con color, sangre con sangre.

\footnotetext{
En el más resistente, más velado

Lugar del corazón, mete las manos

El silencio del mundo, mas despierta

Al pájaro mortal, al destinado.

Habla en dura quietud, habla en la nieve.

La geografía del final es blanca.

Pero desciende, corazón repasa

Yerba secreta y el hayedo oscuro

Como la planta antigua del pastor.

Baja a escrutar la transparencia fría,

Entra en el bosquecillo de las venas, siente

Los arroyos pacíficos, el ruido

Denso y materno de la leche, escucha

Los pasos cautelosos de las bestias.

Cruza la sombra con tu cuerpo, pasa

Sobre las huellas comunales, duerme

En el silencio como un dios cansado

Y, luego, acude al sobresalto puro,

A la fresca, gloriosa desbandada

De las aguas en júbilo, discierne
} 
Repartida en la luz, pálida espuma.

Pero vuelve al camino: te rodean

Las floraciones de la soledad,

Los árboles salvajes, los helechos,

Los invisibles manantiales. Calla.

Exprésate con sola tu existencia,

Como el bosque secreto, que se dice

En la ciega madera y en el liquen

$\mathrm{Y}$ en la profundidad y en la quietud.

Lívida, verde, añil, precipitante

Golpea el agua en la afilada estirpe

De la roca fluvial. Ya no recuerdas

Ningún canto ni el manso y solitario

Campanil del ganado, Sólo sientes

Un único latido, una corona de piadosa

Humedad en tu cabeza.

Ya no recuerdas en el quicio raudo,

En la inmóvil, hirviente cabellera,

En el abismo azul, en el espanto.

En el espanto, en la invisible túnica

Del huracán, en la feroz escala

Del que canta ante el rostro de la muerte (Gamoneda, 2004, 149).

Otro aspecto que gira como satélite esencial entorno de estas sus órbitas, la del poeta y el mundo, es la experiencia del devenir del tiempo y que conforma una experiencia de temporalidad. Para el gran excluido, para el pensador de la substancia infinita cuya esencia deviene a través de las cosas todas; para el pulidor de lentes, llamado Benito Espinosa, la duración se inscribe en la experiencia del propio cuerpo al que conmueven los otros cuerpos. De forma tal que, sintiéndose afectado, hace en él experiencia una pasión; un modo y grado de la afección y que, en la conciencia de su intensidad y modulación, se expresa en él como afecto.

Pasión, intensidad, modulación y duración parecen ser los aspectos propios de nuestra conciencia afectiva; de forma que algunos poemas de Gamoneda son la cosecha en la que el recuerdo de lo vivido, del instante de vida, tanto como del olvido, se convierten en la luz que ilumina los paisajes de su conciencia.

Cuando yo tenía catorce años,

Me hacían trabajar hasta muy tarde.

Cuando llegaba a casa, me cogía

La cabeza mi madre entre sus manos.

Yo era un muchacho que amaba el sol y la tierra

Y los gritos de mis camaradas en el soto

Y las hogueras en la noche

Y todas las cosas que dan salud y amistad

Y hacen crecer el corazón.

A las cinco del día, en el invierno,

Mi madre iba hasta el borde de mi cama

Y me llamaba por mi nombre

$\mathrm{Y}$ acariciaba mi rostro hasta despertarme. 
Yo salía a la calle y aun no amanecía

Y mis ojos parecían endurecerse con el frío.

Esto es lo justo, aunque era hermoso

Ir por las calles y escuchar mis pasos

Y sentir la noche de los que dormían

Y comprenderlos como a un solo ser,

Como si descansaran de la misma existencia,

Todos en el mismo sueño (Gamoneda, 2004, 105).

La conciencia del poeta recrea, con los entramados antedichos, un territorio que deviene paisaje; un paisaje del alma y un paisaje habitado de humanidades. Allí, la experiencia demanda al Logos poético una roturación que, a través del lenguaje del mundo, trace sus reconocibles perfiles. En esta dirección, como he tratado de mostrar, Gamoneda consigue que se haga la luz, en forma de correspondencia entre su experiencia vital y su conciencia. En él, el Logos poético se muestra tal cual es, tiempo, sonido y un corazón tan pleno como oscuro; siendo su poesía, como la labor del cincel en la mano del escultor: precisión en el lugar y en la fuerza.

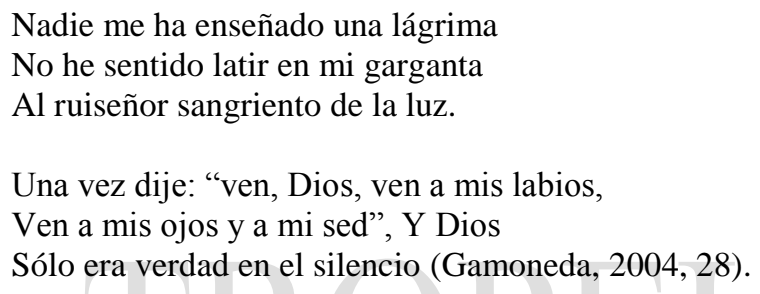

No es de extrañar ese temor sacro del pensamiento filosófico al discurrir poético; porque es ahí donde la razón da a la vida humana los instrumentos para representarse y construirse un mundo de orden y poder; allí donde la necesidad impera, cruel, desde la jerarquía de cada función. Platón sabía -por una experiencia que casi lo degrada a ser no libre-que no hay reforma que en los hombres puedan practicarse que no se enraíce en su corazón y que, al mismo tiempo, no se represente en su mente. Allí donde el pensamiento filosófico quiera instrumentalizarse y ejercer su poderío para someter bajo canon, dietas y pasos medidos a las hechuras del ser humano, el Logos poético pone la inefable vivencia de la belleza que todo lo devasta con un placentero olvido o un deseo sin límite.

El tiempo ha pasado, sin darnos cuenta, hasta que aquellos lugares de nuestra vida nos muestran los efectos de los cambios que nos afectan y que llegan a trastocar esa otra existencia que habita y nos acompaña en nuestra memoria. Guardamos la imagen de los instantes y de la duración de los afectos que nos provocaron, perpetuándose en nosotros hasta que los volvamos, forzosamente, a contemplarlos desde el borde de los propios años transcurridos.

Esta hora no existe, esta ciudad no existe, yo no veo estos álamos, Su geometría en el rocío.

Sin embargo, éstos son los álamos extinguidos, vértigo de mi infancia.

Ah jardines, ah números (Gamoneda, 2004, 341). 
Pero hay otros casos, raros, en los que el poema muestra su cosecha con una honestidad forense; impidiendo cualquier tipo de solaz o complacencia. Son poemas límpidos, que no se prodigan en símbolos, aunque exigidos en las metáforas. Las razones se hacen pavorosamente claras, honradamente expuestas como llagas de la existencia, del pasado compartido o de lo que pudo nacer allí, en nosotros mismos. No hay lugar para el recreo ni la compasión: allí la poesía no canta, aunque tampoco sermonea. Tampoco es testimonial, porque no es crónica que da cuenta ni enumera lo acontecido. Es memoria viva. Justicia poética en el sentido propio de la palabra: poema que expone un mundo al juicio.

Era un tiempo equivocado de pájaros. No existía otra luz que la de una gran sábana cuya urdimbre desconocíamos. La cal hervía amenazada por la sombra y los pasillos conducían al zaguán del miedo. Algunas madres se inclinaban para escuchar el llanto de hijos asidos al delantal sangriento.

El jaramago estuvo dentro de mi boca. La envidia avanza como aceite sobre cartones amarillos y Juan Galea, con una espuerta de ira, baja despacio a la misericordia.

Hoy es el día del acero; su resplandor entra en los ojos de los muertos.

Madre indistinta, líbrame de quien se oculta entre palomas, cubre mi rostro,

Sálvame del viernes (Gamoneda, 2004, 245).

Pueda la palabra decir, al tiempo, al hombre y su mundo. Pueda su palabra resonar de humanidades, de temores y esperanzas. Pueda su palabra, en atención al hombre y al terruño y al cernícalo y a la piedra, ser, no ya sonido medido en fonemas precisos, sino eco que es resonancia de los sentidos, celosamente guardados y que retoman su canto ante la agraciada aparición de Cecilia en la vida del poeta Gamoneda:

Estaba ciego en la lucidez

Pero tú ha hecho girar la locura.

Todo es visión, todo está libre de sentido (Gamoneda, 2004, 496).

\section{Referencias bibliográficas}

ARISTÓFAnes, Las ranas, ed. Manuel Rodríguez Adrados, Madrid, Cátedra, 2004.

AZARA, Pedro, La imagen y el olvido: el arte como engaño en la filosofía de Platón, Siruela, Madrid, 1995.

BlumenBerg, Hans, La posibilidad de comprenderse, Madrid, Síntesis, 2002.

BuXTON, Richard, El imaginario griego, Madrid, Akal/Cambridge University Press, 2003.

CoLLI, Giorgio, La naturaleza gusta de esconderse, Madrid, Siruela, 2008.

DURAND, Gilbert., La imaginación simbólica, Buenos Aires, Amorrortu, 2007.

ECO, Umberto, Los límites de la interpretación, Barcelona, Lumen, 1998.

FRÄNKEL, Hans, Poesía y filosofía de la Grecia arcaica: una historia de la épica, la lírica y la prosa griegas hasta la mitad del siglo quinto, Madrid, Visor, 1993.

García CALVo, Agustín, Lecturas presocráticas, Madrid, Lucina, 1981.

GoodY, Jack, The interface between the written and the oral, Madrid, Cambridge University Press, 1987 (reimp.1989). 
— L La domesticación del pensamiento salvaje, Madrid, Akal, 1977, trad. castellana, 1985.

Havelock, Eric, A., Preface to Plato, Belknap Press of Harvard U. P., 1963 (trad. cast. Prefacio a Platón., Madrid, A. Machado libros, 2002).

- The literate Revolution in Greece and its cultural Consequences, Princeton U. P., Princeton, 1982.

HeIDEGGER, Martin, De camino al habla, Barcelona, Serbal, 1990.

Hesíodo, Teogonía, en Obras y fragmentos, Madrid, Gredos, 2006.

HorkHEIMER, Max, y AdORno Theodor W., Dialéctica de la Ilustración, Fragmentos filosóficos, Obras Completas, vol. 3, ed. R. Tiedemann, Madrid, Akal, 2007.

MACHADO, Antonio, Antología de su prosa, pról.y selec. de Aurora de Albornoz, vols. II y III, Madrid, Cuadernos para el Diálogo, 1970 y 1971.

PARMÉnides, Poema, fragmentos y tradición textual, A. Bernabé, J. Pérez de Tudela (eds.), Madrid, Istmo, 2007.

Platón, 1971, La República, México, Universidad Autónoma de México.

RAD, Gerhard von, El libro del Génesis, Salamanca, Sígueme, 1988.

REDFIELD, James M., Nature and Culture in the Iliad: The Tragedy of Hector, Chicago, University of Chicago, 1975 (trad cast. Barcelona, Ediciones, Destino, 1992).

SARTRE, Jean Paul, Lo imaginario. Psicología fenomenológica de la imaginación, Buenos Aires, Losada, 2005.

SCHELLING, Friedrich, Filosofía del arte, Madrid, Tecnos, 1999.

SPERBER, Dan, El simbolismo en general, Barcelona, Anthropos, 1988.

Todorov, Tzvetan, Teorías del símbolo, Caracas, Monte Ávila, 2011.

Vernant, Jean-Pierre, Mythe et Pensée Chez Les Grecs, París, Librairie François Maspero, 1965.

ZAMBrano, María, Obras Reunidas: primera entrega, Madrid, Aguilar, 1971. 